[JSRNC 10.1 (2016) 91-116]

JSRNC (print) ISSN 1749-4907

doi: 10.1558/jsrnc.v10i1.21368

JSRNC (online) ISSN 1749-4915

\title{
In Search of Religious Elements in the Dutch Nature Policy*
}

\author{
Peter Jansen \\ Wageningen University, Social Science Group, \\ Sub-department Communication, \\ Philosophy and Technology, \\ Hollandseweg 1, 6706 KN, Wageningen, The Netherlands \\ peter.jansen@wur.nl \\ Jan van der Stoep \\ Ede Christian University for Applied Sciences, \\ Academy for Journalism and Communication Studies, \\ P.O. Box 80, 6717 JS, Ede, The Netherlands \\ jvdstoep@che.nl \\ Jozef Keulartz \\ Radboud University, Faculty of Science, \\ Institute for Science, Innovation and Society, \\ P.O. Box 9010, 6500 GL, Nijmegen, The Netherlands \\ J.Keulartz@science.ru.nl \\ Henk Jochemsen \\ Wageningen University, Social Science Group, \\ Sub-department Communication, Philosophy and Technology, \\ Hollandseweg 1, 6706 KN, Wageningen, The Netherlands \\ henk.jochemsen@wur.nl
}

\begin{abstract}
The way people or organizations describe or depict nature conveys their view of nature. In the Dutch discourse, views of nature are mostly conceived as socio-cultural constructs regarding the character, value, and appreciation of nature. Views of nature tell us how we perceive nature and
\end{abstract}

* This work was supported by the Netherlands Organization for Scientific Research (NWO) under grant number 023.001.002. 
how we want to relate to it. Likewise, they shape our preferences for certain types of nature. Views of nature function as frames and provide an interpretive and reflective context for our experiences with nature. Views of nature are also digestions of meaningful experiences. It is through communication that we become aware of such experiences. We argue that meaningful experiences have religious depth. On the basis of this argument any discourse on nature contains, in a sense, religious subtexts. We examine the Dutch discourse on nature.

\section{Keywords}

Nature policy, views of nature, frames, experiences, religion.

At the end of the twentieth century the Dutch government came to the conclusion that Dutch nature had limited ecological sustainability as a result of substantial habitat fragmentation. The Dutch Nature Policy Plan of 1990 (Ministry of Agriculture, Nature and Fisheries [Ministerie van LNV] 1990) aimed to compensate for this lack of connectivity by creating a coherent network of nature reserves throughout the Netherlands, the so-called National Ecological Network (Ecologische Hoofdstructuur). With the National Ecological Network, the emphasis shifted from the conservation of 'old' nature to the development of 'new' nature, that is, from a defensive to an offensive strategy: a concept known as 'nature development'. Nature development involves technical interventions, often with respect to areas of land that were formerly used for agriculture, in order to create suitable habitat conditions, after which natural processes are given free rein. In short, nature development refers to rewilding through human intervention. Even though nature development was not the only goal of this former nature policy plan, it can be considered as one of the most remarkable and far-reaching objectives according to Zwanikken (2001); not the least because the development of nature is not entirely uncontroversial. ${ }^{1}$ In the Netherlands there is an ongoing battle with regard to nature, 'often fought in grimness and bitterness' (Keulartz 2000: 75). ${ }^{2}$ This controversy indicates that 'nature' is

1. Zwanikken (2001) mentioned three themes that dominate the discourse surrounding the National Ecological Network: (1) varying views of nature referred to in the general public debate, (2) the debate regarding the segregation or synergy of nature with other functions, and (3) the question of whether an ecological network throughout the Netherlands is the correct instrument for shaping nature conservation policy.

2. Drenthen interestingly argued that the discussions are not about whether nature is desirable, but rather about the question as to whether the 'nature that actually exists in the Netherlands (can be) called "really" natural' combined with the 
a concept that arises in relation to 'social concerns and ideological agendas' (McGrath 2001: 82) or 'foundational beliefs and values' (RossBryant 2013: 4).

In this study we seek to gain insight in the complicated and unique Dutch discourse on nature. ${ }^{3}$ In the first part of the article we provide a socio-historical overview of Dutch nature policy, and we discuss the particular way nature has been constructed, experienced, and managed in the Netherlands. Subsequently, in the second part of this article we are interested in the question as to whether in the discourse about nature in the Netherlands religious elements can be identified.

\section{Socio-historical Context of the Dutch Nature Policy}

It was only in the early twentieth century that views on nature and conservation became part of the public discourse and policy-making in the Netherlands (Zwanikken 2001). The period up to 1990 was marked by an increase in focus on conservation and the implementation of defensive nature policies: the objective being to retain existing nature reserves and resources. Despite attempts to preserve what was already established, circa 1990 it was concluded that a lot of ground had been lost and that nature had drawn the shortest straw (Kockelkoren 2000). Table 1 shows the phased progression of nature policy in the Netherlands until the 1990s.

Table 1. Phases in the emergence of Dutch nature policy

\begin{tabular}{|l|l|l|}
\hline Period & Qualification & Description \\
\hline Pre-1920 & Developing & $\begin{array}{l}\text { The popularization of knowledge of the natural world } \\
\text { resulted in an increase in interest in nature and conserva- } \\
\text { tion. The first botanical society was founded in 1845. The } \\
\text { first books on birds and flowers and plants soon } \\
\text { followed. Public interest was further boosted through the } \\
\text { efforts of E. Heijmans and Jac. P. Thijsse, who first } \\
\text { published the journal The Living Nature (De Levende } \\
\text { Natuur) with J. Jaspers Jr. in 1896. The State Forestry } \\
\text { Organization (Staatsbosbeheer) was founded in 1899 to } \\
\text { manage state nature reserves and oversee wood produc- } \\
\text { tion. In 1901 the Dutch Natural History Association } \\
\text { (Nederlandse Natuurhistorische Vereniging) was founded }\end{array}$ \\
\hline
\end{tabular}

question as to 'whether naturalness is actually feasible within the Dutch context' (2003: 11).

3. Here we follow Hajer in his description of discourse: an ensemble of ideas and concepts that are 'produced, reproduced and transformed in a particular set of practices' (1995: 44). 


\begin{tabular}{|c|c|c|}
\hline & & $\begin{array}{l}\text { with nature conservation as an aim. The first key battle } \\
\text { for nature conservation took place in } 1904 \text { when the city } \\
\text { of Amsterdam moved to dump its refuse in the waters of } \\
\text { the Naardermeer. This provoked a backlash in the news- } \\
\text { paper Algemeen Handelsblad (Thijsse) and in the magazine } \\
\text { Groene Amsterdammer (Heijmans), resulting in funds } \\
\text { being raised to purchase the Naardermeer. The following } \\
\text { year marked the founding of the Association for } \\
\text { Preservation of Natural Monuments in the Netherlands } \\
\text { (Vereniging tot Behoud van Natuurmonumenten) and the } \\
\text { acquisition of the Naardermeer. }\end{array}$ \\
\hline 1920-30 & Expanding & $\begin{array}{l}\text { In } 1929 \text { nature conservation became a key task of the } \\
\text { State Forestry Commission (Staatsbosbeheer). The so- } \\
\text { called Provincial Landscape Commissions (Provinciale } \\
\text { Landschappen) were founded soon after with the objective } \\
\text { of setting up and managing nature reserves at a } \\
\text { provincial level. Conservation organizations also began } \\
\text { exercising political pressure, resulting in government } \\
\text { policy, e.g., the Forestry Law (Boswet) of } 1922 \text { and the } \\
\text { Nature Law (Natuurschoonwet) of } 1928 \text {. }\end{array}$ \\
\hline $1932-45$ & Testing & $\begin{array}{l}\text { Hard times due to the economic crisis and World War II. } \\
\text { Employment became the top priority, resulting in large- } \\
\text { scale exploitation of natural resources and reparcelling of } \\
\text { land. }\end{array}$ \\
\hline $1945-60$ & Defending & $\begin{array}{l}\text { Post-war reconstruction, population increase, and } \\
\text { growth in prosperity all posed a threat to nature: urban } \\
\text { expansion, road works, industrialization, increased } \\
\text { intensive farming, etc., increasingly affected natural } \\
\text { areas. }\end{array}$ \\
\hline $1961-69$ & Recognition & $\begin{array}{l}\text { Detrimental effects of prior developments resulted in a } \\
\text { breakthrough in awareness. Nature conservation was } \\
\text { given recognition by policymakers and the general } \\
\text { public. Demand for outdoor recreation increased, natural } \\
\text { and environmental education was established, and in } \\
1967 \text { the Nature Law (Natuurbeschermingswet) was } \\
\text { passed. Despite this, farming expansion and reparcelling } \\
\text { of land continued. }\end{array}$ \\
\hline 1970-80s & Reflection & $\begin{array}{l}\text { The economic downturn of the } 1970 \text { s and ' } 80 \text { s resulted in } \\
\text { limited government spending; the budget for nature } \\
\text { conservation was insufficient to halt further deterioration } \\
\text { of nature reserves. At the same time a broader reflection } \\
\text { had been taking place on the future of nature policy. A } \\
\text { debate emerged regarding the segregation or synergy of } \\
\text { functions, particularly between nature and farming. } \\
\text { Twenty-four national parks were established. }\end{array}$ \\
\hline
\end{tabular}

Source: Gorter 1996. 
Zwanikken (2001) claimed that the heightened environmental awareness during the 1970s and the emergence of a unique nature reserve called the Oostvaardersplassen ${ }^{4}$ as a result of human 'abstinence' leaves room for 'the notion that nature is no obsolete, historical category, but rather a category that is always open to human opportunity' (2001: 136). A so-called 'policy window' occurred, in which problems, policies, and politics coincided. ${ }^{5}$ The most interesting element in Dutch nature policy since the 1990s has been the concept of 'nature development' (natuurontwikkeling), which refers to creating 'new nature' (nieuwe natuur): rewilding through human intervention. As an offensive strategy, nature development has facilitated a new way of thinking about nature as well as a change in the mind-set regarding spatial planning and zoning. In a sense, nature development can be seen as a typically Dutch and inherently paradoxical concept. ${ }^{6}$

\section{The Re-emergence of Wilderness}

The Netherlands is said to be a human-made country; consequently, the repurposing of land for nature development was initially met with resistance. Zwanikken (2001) characterized the debate as being principally about the relationship between culture and nature and the question

4. The Oostvaardersplassen form a nature area of approximately $56 \mathrm{~km}^{2}$ located between Almere and Lelystad in the Dutch province of Flevoland. Following the reclamation of the Flevopolder in 1968 this wet land remained unused. Nature saw its chance and a marsh formed, with pools, reed beds, and willows. At the moment the area consists roughly of a wet part (approx. 3,600 ha) and a dry part (approx. 2,000 ha). The dry part is regarded as a suitable habitat for large herbivores. The Oostvaardersplassen are of international importance as marshland and as a wintering site for birds. In 2013 a film was made about this area entitled The New Wilderness (de Nieuwe Wildernis).

5. Metz (1998) argued that at that time there was awareness of natural and environmental issues, such as the near extinction of the otter. An equally important factor she highlighted is the breakthrough in attitudes regarding farming and agricultural policymaking: 'At the time the prediction was that the decline of agriculture would result in a surplus of some 700,000 hectares. The breakthrough in politics came at the end of the eighties under the third Lubbers cabinet (1989-1994), which allocated more funding for nature and the environment. At the same time, intriguing policies were being floated: ideas on the spontaneous development of nature, inspired by the living example of the Oostvaardersplassen, quickly gained popular support' (Metz 1998: 187).

6. The concept of 'nature development' has a great deal in common with 'nature restoration' or 'restoration ecology': the effort to restore ecosystems that humans have turned into agro-ecosystems, human settlements, or extractive areas.

(c) Equinox Publishing Ltd 2016.

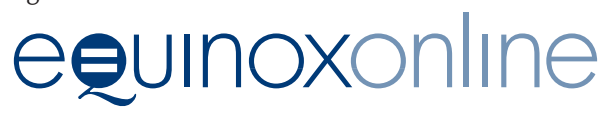


as to which frame of reference should be used in regard to nature development. The choice of frame of reference for nature to be (newly) developed is connected to views of nature. ${ }^{7}$ Views of nature are often categorized on the basis of the degree of human influence on nature and the question of whether or not to allow natural processes. When we look at the views of nature within Dutch nature policy, three dominant understandings stand out: the wilderness view of nature, the Arcadian view of nature, and the functional view of nature, summarized in the alliteration 'reposeful' (rustig), 'rough' (ruig), and 'rational' (rationeel) (Keulartz, van der Windt, and Swart 2002).

Henny Van der Windt et al. (2007) pointed out that until the 1980s and ' 90 s the ninteenth-century agrarian landscape acted as a key reference point because of its high level of biodiversity and its cultural value. They further claimed that most nature organizations in the Netherlands maintained an Arcadian view of nature. Vera (2000) characterized the Arcadian view of nature as an image of a harmonious coexistence between nature and culture. The Arcadian view of nature focuses on rural nature - on nature that is characterized by a human-made landscape in which patterns from the past can be observed (Keulartz 2000; Van Koppen 2002). This perspective is idealistic and sees the pre-industrial landscape of the eighteenth-century landscape painters as a source of inspiration and retrospection (Keulartz 2000; Lemaire 2007 [1970]). Chris S.A. Van Koppen (2002) spoke of a dual understanding of the concept 'Arcadia' that appreciates not only cultivated, rural nature, but also elements of wilderness, demonstrating a dialectic tension between the 'Arcadian' and the 'wilderness' view of nature. There are similarities, however, as well: the 'wilderness' and 'Arcadian' views of nature romanticize or idealize nature in a certain way. ${ }^{8}$ The following quote from a public communication of Tiengemeten, a well-known nature development project in the Netherlands, is illustrative of this romanticism:

Human-sized brush and grassland, dissected by a dozen streams. Highland cattle with their legs in the water and a gap in the dike. Thousands of birds of all kinds and sizes. Chaos and silence. This is the

7. With regards to nature in Dutch discourse, scholars mostly speak about images of nature (natuurbeelden). To avoid 'scenic' or 'picturesque' connotations, and because our view of nature is strongly related to our world view, in this article we prefer 'views of nature' to 'images of nature'.

8. Van den Born and De Groot (2011) concluded that the Dutch romanticize nature. Empirical research by De Groot and van den Born showed that the spiritual/romantic image of participation in nature is present as an undercurrent' among the Dutch. The large majority of their respondents preferred 'wild and experiential landscapes types' (De Groot and van den Born 2003: 134).

(c) Equinox Publishing Ltd 2016.

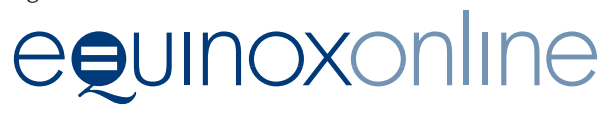


kind of wilderness we have missed. This is Tiengemeten the primeval delta now!... It's quiet in the Wilderness. Quiet and yet bustling with life... The hill is the best vantage point to catch a panoramic view of the Wilderness, the Haringzliet with its locks and fixed embankment on either side. A safe place 'separated from the world' (Natuurmonumenten n.d.: 1,6).

Ever since the 1980s there has been a reemergence of the wilderness ideal in the Netherlands (Buijs 2009). Vera (2000) characterized the wilderness as the 'primitive image' in the philosophy of nature. According to this view, nature has an untamed and pristine character and because of that it is regarded as something primordial. It refers to uninhabited and uncultivated spaces and to an 'environmental system where natural processes occur with little or no significant influence by human beings' (B. Taylor 2012: 293). According to Drenthen (2003: 200), the wilderness approach builds on the idea 'that wild, uncultivated nature represents an important value that is to be protected from cultivation and appropriation by humans'. In effect, wilderness is one extreme on the scale of decreasing naturalness and increasing human influence. The other extreme is the functional view of nature, which holds that nature is an object of production: a view of nature with a strongly anthropocentric character. Or as Arjan Buijs et al. suggested:

The wilderness image is based on ecocentric values of nature and a very narrow definition of the concept of nature, related to the autonomous development of nature. The functional image, on the other hand, focuses on anthropocentric values in which nature should be intensively managed, for aesthetic as well as utilitarian purposes. Within this image, nature and culture are not seen as opposites; humans are supposed to master nature (Buijs, Elands, and Langers 2009: 114).

Van der Windt, Swart, and Keulartz (2007) have suggested that the reemerging idea of wilderness, or autonomous nature, became a topic on the political agenda as a result of the efforts of the action groups in the 1980s-1990s. These ecologically minded groups demanded that attention be devoted to the repair of entire ecosystems and campaigned against the economic exploitation of forests. ${ }^{9}$ The ecological reference point

9. During the 1980s the Dutch branch of the WWF advocated the development of ecosystems that were to remain more or less free from human influence because of the intrinsic value of nature or for reasons of extensive recreation. Van der Windt, Swart, and Keulartz (2007) stated that there were efforts to realize these ecosystems along the rivers, as it was expected that here the greatest natural diversity could develop. Furthermore, they pointed to the fact that from the 1990s on more traditional NGOs also became interested in wilderness. Van der Windt, Swart, and Keulartz (2007) argued that these developments were reflected in government policy, as evidenced by the relevant policy documents. 
started to act as a criterion for assessing the current state of nature and as a basis for the formulation of policy objectives. Here the central question is how nature would have been if it had not been exposed to culturally informed human interventions. In 1989 a policy document called Nota Nature Development linked the ecological reference point to prehistorical, primeval nature (Ministry of Agriculture, Nature and Fisheries [Ministerie van LNV] 1989). The underlying thinking was that nature functioned at its best before it was influenced by humans. The Dutch Nature Policy Plan of 1990 (Ministry of Agriculture, Nature and Fisheries [Ministerie van LNV] 1990) expanded the ecological reference point. Rather than referring to something vague, such as 'prehistoric nature', it refers to what is generally considered to be the last vestige of wilderness: primeval forest in Europe, namely the Białowieża Forest (Puszcza Białowieska) in Poland.

From the above discussion we may conclude that the concept of 'nature development' with the emphasis on 'primeval nature' or 'autonomous nature' was primarily an ecological frame. The question arises as to how nature development came to resonate so strongly within society that it could dramatically shape Dutch nature policy. To answer this, we will explore the 'new nature paradox', as we call it.

\section{The New Nature Paradox}

The concept of nature development is linked to that of 'new nature'. The 'creation of savage nature' is something Matthijs Schouten (2002) considered to be a novelty in history. He also foregrounded other notions about primary nature:

The final decade of the twentieth century, in which the boundary between urban and rural largely disappeared and Arcadia came to resemble an agrarian industrial park, saw the rebirth of the myth of virgin wilderness. And of that of the noble savage, who was elevated to a conservationist avant la lettre... In the past primeval wilderness was largely seen as dense forest. Now, certain ecologists depict it as an open woodland landscape in which herds of large herbivore roam. In addition, the swamp, which was previously seldom ascribed a positive role in the wilderness myth, now gains an aura of venerable age (Schouten 2002: 33)..$^{10}$

10. In this context Van der Woud wrote: 'The cultural landscape is also disappearing because propaganda is made for another, brand-new landscape image, and we are being manipulated to like that image... The liberation of nature started in 1990 with the National Ecological Network and an end was put to... a four-centuries-old national tradition of land reclamation... We cannot deny that this new nature has an important ethical dimension. It gives the impression of having a prehistoric or early medieval antiquity - a landscape that existed before humans began to tinker with it and began to enslave nature' $(2007: 3,10,11)$.

(c) Equinox Publishing Ltd 2016.

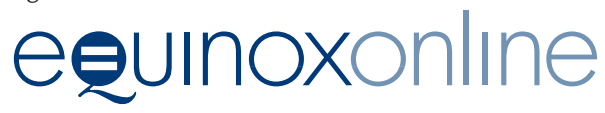


Hub Zwart called for a radical shift in attitudes: one that respects 'exalted primeval nature' and criticizes the 'view of nature of the [Dutch] Golden Age (seventeenth century) and that of modern engineers' (2002: 46). This shift is a recurrent topic in the discourse on nature, sometimes referred to as 'new thinking', exemplified in the following quote:

Tiengemeten: new nature, breaking ground like the water of its creeks. The symbol of new thinking, of trust in the shaping capacity of nature. Primeval nature, nature that seems to have been ever-present (Natuurmonumenten n.d.: 17).

Intriguingly, the new nature concept is in itself paradoxical. It links with current ideas on engineerability and technology, whilst striving to achieve a prehistorical primeval type of spontaneous nature independent from humankind. Kockelkoren (2000) regarded the fear of the encroaching technological culture-which had resulted in a reduction in natural diversity in the Netherlands over a short period of time-to be a feeding ground for the ideal of autonomous nature and the idea of nature development. In a sense, however, it is also a technical understanding of wilderness nature, the result of 'a slow-motion ballet méchanique of draglines and bulldozers, excavators and trucks' created 'under the direction of engineers and geomorphologists' (Hajer 2003: 90).

The above discussion illustrates that attitudes toward wilderness have changed in the Netherlands. Previously, the ideal of unspoiled wilderness was projected on or recognized in existing nature reserves that were protected from human influence. Nowadays, the desire for wilderness serves as justification for human interventions in the context of the creation of 'new' nature, of which the National Ecological Network is a good illustration (Drenthen 2003). In this respect, Jozef Keulartz (2009a) speaks of the 're-creation' metaphor, which stresses authenticity. ${ }^{11}$

The use of technology regarding nature employed by the Dutch is by no means new. Zwart (2002) noted that land-engineering practices began around $800 \mathrm{CE}$, with dykes being built, waters drained, and land reclaimed. He argued that a more active attitude regarding nature developed from that period onward that included the cultivation of the Netherlands. He linked this process to what he regarded as the ideological shift taking place during that time: the 'christianization of the low countries' (kerstening van de lage landen). For example,

11. For Keulartz (2009a), authenticity had always been the guiding element within the world of conservation, but slowly there has been a shift from the conservation and protection of existing nature to the development of 'new' nature. In this respect he speaks of a shift from the 'restoration' metaphor to the 're-creation' metaphor.

(c) Equinox Publishing Ltd 2016.

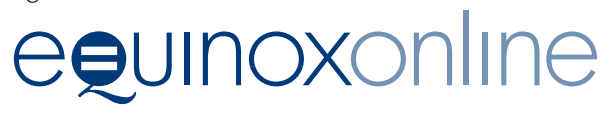


Christians regard themselves as stewards of God, charged with rehabilitating nature that has run wild and providing it again with a human dimension... Christianity provided the impetus and legitimized a more active presence of humans in the Dutch landscape. The dyke served to demarcate the Christian and non-Christian world (Zwart 2002: 40).

If, as Zwart (2011) argued, most transformations of the countryside are linked to Christian-conversion offensives, then conversely there may also be a correlation between 'depoldering' and secularization, ${ }^{12}$ between the rise of new nature and a shift in spiritual experience. Interestingly, Bron Taylor observed that the efforts to establish and protect wilderness areas can be understood 'to be a way of establishing such places as sacred places, as temples for those who have left behind conventional religions' (2012: 310). By this he implied that 'wilderness' has acquired religious meanings.

\section{Nature Experience}

The past decade has notably seen even greater emphasis on nature experience (natuurbeleving) in Dutch nature policy. ${ }^{13}$ Kockelkoren (2000) suggested that near the millennium a shift took place. Buijs referred to 'a shift from an ecological focus to a combination of an ecological and societal focus' (2009: 17). This change- 'to include the social values of nature' - is illustrated by the title of the second Dutch nature policy plan: 'Nature for people, people for nature' (Ministry of Agriculture, Nature and Fisheries [Ministerie van LNV] 2000). The plan works on the principle that nature should match the needs and desires of Dutch citizens. Nature should be at the heart of society (Keulartz 2009b). Buijs suggested three changes that this plan entails: (1) a shift of focus away from ecological values to a broad range of values, including the 'experience value of nature'; (2) a broader definition of nature, which not only includes

12. In the past the Dutch have wrested land from the sea by turning the swampy and unstable river delta into a country with a strong agricultural identity. This process is known as 'inpoldering'. Nowadays, for nature-development reasons, a lot of farmland is to be flooded again, a process called 'depoldering', which means 'giving land back to the water'.

13. Buijs (2009) pointed to individual needs, motivations, experiences, and behaviour becoming more and more diverse. This was illustrated by a study $(43,365$ respondents) carried out by Natuurmonumenten at the end of 2014: participants preferred a personal experience of nature; tranquility, purity, and natural beauty are cited as key aspects when visiting nature. The use of language in the study is intriguing. Reference is made to a 'nature experience agenda' and an 'experience package'. Another interesting aspect is the approach of Natuurmonumenten that 'nature conservation starts with experiencing nature', because 'an environment we [feel] connected to...is worth cherishing' (2014: 9). 
officially recognized nature reserves, but also green belts in cities and agricultural areas which may also have ecological value; and (3) a collaboration among farmers, citizens, and private companies-that is, the 'incorporation of several non-governmental actors in the implementation of nature-related policies' (2009: 18).

In 2014 the Dutch government presented its vision for the future, which shifted focus from the protection of nature from society to the strengthening of nature by society. In terms of the policy document, the focus is on 'nature that needs no protection from society, but rather is an inextricable and vital part of that society' (Ministry of Foreign Affairs [Ministerie van Economische Zaken] 2014: 7). The document claims that the distinction between 'true' nature and 'other' nature is outdated. Furthermore, it refers to 'human self-interest', given that citizens require nature to 'recuperate', seek 'excitement and wonder' in nature (2014: 6, 14), and wish not only to protect nature but also 'to experience and make use' of it (2014: 16). Nature development is no longer only driven by the ideal to restore 'pure nature' for the sake of nature herself, but also by the value which such nature has for the human experience.

Buijs flagged an increase in what he called 'post-material values', with urbanization and a fast-paced daily existence resulting in an increase in nature-related leisure activities. He additionally referred to a 'consumption of natural areas' (2009: 19) that is primarily symbolic, as people mainly pay attention to the symbolic meaning of a natural area: 'Traditional rural areas remind us of bygone days, while the emergence of new life in spring reminds us of the spiritual or divine basis of human life, and the decay in autumn reminds us of our mortality' (2009: 19).

Alister McGrath interestingly argued that in Western thought the term 'nature' has the connotation of innocence and nostalgia-the memory of a distant rural past in which 'the simplicity and beauty of nature is contrasted with the artificiality and ugliness of human conventions and creations' (2001: 82-83). In other words, he spoke of the romanticization of nature. Romanticism in particular has been crucial to our current way of thinking about wilderness and is at the root of the current nature and environmental movements, according to authors such as Roderick Nash (2001 [1969]) and William Cronon (1995). However, romanticism is difficult to define. In general, it implies an enthusiasm for the strange, the distant, the lonely, and the mysterious (Nash 2001 [1969]). Romanticism consequently has a preference for wildness and for the primitive, as Nash suggested: ${ }^{14}$

14. Nash pointed out that this has had far-reaching consequences for our thinking about wilderness: 'The concept of the sublime and picturesque led the way by

(c) Equinox Publishing Ltd 2016.

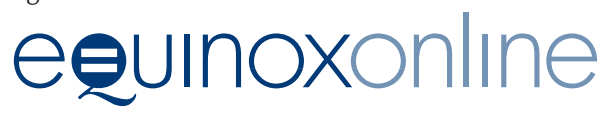


Primitivists believed that human's happiness and wellbeing decreased in direct proportion to his degree of civilization. They idealized either contemporary cultures nearer to savagery or a previous age in which they believed all men led a simpler and better existence (Nash 2001 [1969]: 44, 47).

Along this line of thought, Hans Ester wrote that one of the benefits of Romanticism was 'that nature was no longer seen as a self-sustaining mechanism, but as an animate organism that appeals to the feelings of humans' (2012: 12). The appreciation of nature in our present century and the fear that vital nature values will perish through rampant consumerism can be traced back to the profound feelings of the Romanticists' (2012: 12). He therefore stressed that Romanticism had a strong religious orientation, and that the emphasis on emotion was not so much a sentimental impulse but an expression of trust in the truth of feeling. True feeling is 'a pure response to the appeal that the divine generates in humans' (2012: 12). Such Romanticist feelings are a source of religion, however much 'The sentimental, romantic attitude with which "romantic" is associated nowadays is a degeneration of the original profundity of the romantic sense of life' (2012: 13).

\section{Theorizing Views of Nature}

It is impossible to discuss nature in a timeless way and in general terms. In every cultural-historical period people talk about 'nature', but always in a different way (Roothaan 2005). ${ }^{15}$ Views of nature are therefore historically situated; Schouten, for example, considered views of nature as cultural phenomena: 'In the way nature constantly brings forth new life and new forms, culture, too, constantly creates new views of nature. In doing so, the variation in perceptions, ideas and views seems hardly inferior to the richness of forms in nature itself' (2005: 9).

enlisting aesthetics on wilderness's behalf while deism linked nature and religion. Combined with the primitivistic idealization of a life closer to nature, these ideas fed the Romantic movement, which had far-reaching implications for wilderness' (2001 [1969]: 44).

15. Angela Roothaan (2005) distinguished in this regard three main periods in Western history. Starting with the pre-modern period (which centered on the experience of the divine order; god is present in nature or the cosmos is created by God), we have moved through the modern period (in which nature functioned according to mathematical laws and was considered to be a neutral object of study) into the postmodern period (in which nature is not neutral but has its own more or less constructed intrinsic value). 
The multiformity of nature- the 'many faces of nature', as McGrath (2001) and Van Koppen (2002) significantly put it-is a reflection of the diversity of lifestyles and life views. Different social interests and different individual lifestyles, wishes, and desires are projected onto nature (Drenthen 2003). McGrath argued that the way in which nature is conceptualized in various cultures provides insights both into these cultures and into the concepts themselves. Accordingly, the 'instability' of the concept of nature illustrates why nature has no fixed references but is defined by communities of discourse (2001: 103). In other words, we need communication to gain an understanding of nature. But each description or conception of nature reflects 'a complex amalgam of religious beliefs, popular sentiment and the vestiges of a classical culture' (2001: 103). The qualification of something as 'nature' always implies a particular view of nature. Such a perspective does not so much provide information about nature as shows how we perceive ourselves in relation to nature (Schouten 2005). Or as Lynn Ross-Bryant argued, 'Nature... grows out of our world view and shapes our ways of acting in the world' (2013: 4). In other words, views of nature can be seen as articulations of our worldview. ${ }^{16}$ In the following, we will further elaborate on this aspect by approaching views of nature as frames.

\section{Views of Nature as Frames}

Keulartz, van der Windt, and Swart (2004) considered views of nature as socio-cultural constructs regarding the character (cognitive dimension), value (normative dimension), and appreciation (expressive dimension) of nature. The cognitive dimension pertains to knowledge of nature. The normative dimension refers to our relationship with nature and the moral status we ascribe to nature. It also pertains to the ethical criteria regarding our relationship with nature. Finally, the expressive dimension concerns the way we experience nature aesthetically and emotionally. Table 2 connects the three major views of nature in Dutch nature policy with the cognitive (ecological theory), normative (ethical perspective), and expressive (aesthetic perspective) dimensions.

16. For David Naugle, 'world views are undoubtedly contextual phenomena enabling people to see things and make connections' (2002: 150). Worldviews define the person and provide humans with 'fundamental assumptions upon which a life is based' (2002: 291). Naugle said that a worldview is 'the primary system of narrative signs that articulate a vision of reality and lie at the base of individual and collective life [and] is the most significant set of presuppositions on the basis of which interpretation operates' (2002: 313). He came to the conclusion that any interpretation of the social and natural world is conditioned by worldviews, including our interpretation of and relation to nature.

(c) Equinox Publishing Ltd 2016.

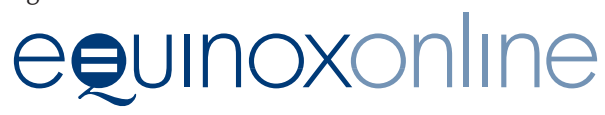


Table 2. Views of nature classified according to their cognitive, normative, and expressive dimensions.

\begin{tabular}{|l|l|l|l|}
\hline & $\begin{array}{l}\text { Ecological } \\
\text { Theory }\end{array}$ & $\begin{array}{l}\text { Ethical } \\
\text { Perspective }\end{array}$ & $\begin{array}{l}\text { Aesthetic } \\
\text { Perspective }\end{array}$ \\
\hline Wild nature & Systems ecology & Ecocentric & Objectivist \\
\hline Arcadian nature & Community ecology & Steward/Partner & Subjectivist \\
\hline Functional nature & Production ecology & Anthropocentric & Formalist \\
\hline
\end{tabular}

Source: Keulartz, van der Windt, and Swart (2004: 93)

With the above points in mind, we conclude that views of nature tell us how we perceive and want to relate to it. Such views similarly organize our preferences for certain types of nature. ${ }^{17}$ Therefore, the literature justly indicates views of nature as frames of reference on the basis of which preferences of nature are formed, and as interpretive frameworks by which experiences with nature gain meaning (Keulartz, van der Windt, and Swart 2002; Buijs, Elands, and Langers 2009).

Frames lead people's thoughts and discourses by presenting the world in a particular way and attributing meaning to human experience. In other words, it is through frames that people are able to make sense of the world, and experiences become meaningful. We frame nature through visual representations as well as through the language we use to describe it (Fig. 1). Such framing entails an interplay between surface frames and deep frames (e.g., Lakoff 2006).

17. Views of nature have a clear relationship with landscape preferences. However, 'an important difference between images of nature and landscape preferences is that images of nature are cognitions about nature (e.g., general values and beliefs). Landscape preferences are usually conceived of as predominantly based on precognitive, affective responses to the physical environment, related to feelings of liking or disliking. They are often defined as the aesthetic or evaluative response elicited by visual encounters with real or simulated natural settings' (Buijs, Elands, and Langers 2009: 114). Furthermore, Buijs, Elands, and Langers noted that 'images of nature have significant power to predict preferences for non-urban landscapes. People with a functional or an inclusive image of nature showed lower relative preferences for natural landscapes, while people with a wilderness image showed a higher relative preference for natural landscapes' (2009: 121). 


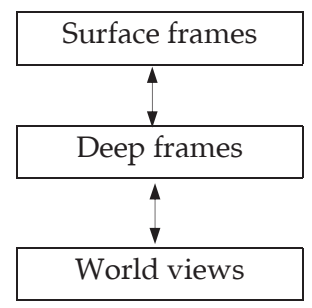

Figure 1. Interplay between frames.

Surface frames function at the level of our daily language. For example, the words 'dark forest' first of all have a descriptive meaning for a certain type of woodland and 'wilderness' refers to a rugged place. Through their immediate meaning, surface frames identify the context of the discourse. However, these surface frames appeal to underlying values and convictions that can be communicated in deep frames and ground our daily language in our normative convictions regarding the world and our lives.

Deep frames articulate our worldviews and hence are more fundamental than surface frames. The frame 'dark forest' is, for instance, associated with feelings of fascination, fear, initiation into a numinous reality, and so forth. Moreover, the frame 'wilderness' has (in the present discourse on nature in the Netherlands) mostly the connotation of pristine and 'real' nature-nature as it originally was before it was affected by humans. Deep frames provide the background we need to interpret something as meaningful. In doing so deep frames provide an interpretive context for our experiences of nature.

\section{Meaningful Experiences}

Experiencing nature as meaningful can influence one's view of it. Buijs, Elands, and Langers spoke of views of nature as 'cognitive reflections of prior experiences with discourses about nature' (2009: 144). Martin Drenthen (2002: 78) likewise suggested that our different interpretations of nature are responses to appealing experiences in nature. For Drenthen, nature presents a pretense of meaning, something that captures our attention, however unconsciously. For this reason, we argue that meaningful experiences precede views of nature, which are (theoretical) interpretations of experiences that we acquire in nature. ${ }^{18}$ At the same

18. This involves some form of interaction: when dealing with such experiences we are directed by our worldviews and at the same time our worldviews are influenced by our experiences, emphasizing the relationship between views of nature and worldviews. 
time, experiences often acquire meaning from people's views of nature. A circular relationship therefore exists between meaningful experiences and views of nature (Fig. 2).

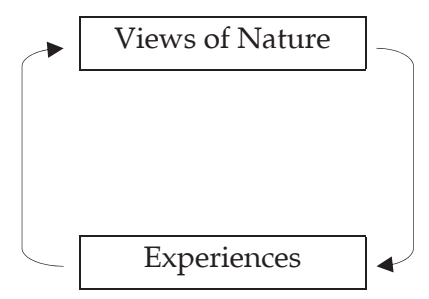

Figure 2. Interplay between views of nature and experiences.

Experiences are often personal and depend on the location. ${ }^{19}$ This makes them difficult to define and examine. Often they cannot be reproduced and are not easily verified. Because experiences are difficult to measure, they must be disclosed through communication. Although the meaning lies in the experience itself, the meaning may only become explicit when it is verbally expressed. When our experiences of nature and our life stories are dialogically connected, nature acquires deeper meaning (Drenthen 2011). It is in communication with others that we articulate our experiences and integrate them into the stories of our lives. To wit:

People always tell stories about [themselves] to an audience, even if that audience is only imaginary-embedded in a relationship and in order to render their storied-selves intelligible, people must draw on narrative resources that circulate more broadly within society-embedded in a social context... People do not tell stories in a vacuum. They learn what types of plots can be told in particular contexts by being exposed to other stories. The plotlines available in any culture or institutional context can be understood as narrative resources (Willis 2011: 93, 101).

In this passage Willis shows that to be processed, experiences need a supporting narrative-in terms of this article, a deep frame-not only to interpret experiences but also to place them within the socio-cultural

19. Although experiences are personal, it remains to be seen if one can speak of purely individual experiences. Some experiences are enhanced by the feeling that they are shared, such as watching a football game together. There are also certain emotions that some can only experience in solidarity with others, such as feelings of comfort and security. What may be considered as an individual experience at first sight is strongly influenced or enhanced by socio-cultural elements (C. Taylor 2003). Experiences may seem available separately, but they should not be considered independently. 
tradition to which one belongs. Apart from orientation, the supporting narrative (= deep frame) offers direction because it contains assumptions about how reality is or ought to be (= worldview) ${ }^{20}$ Charles Taylor (1991) argued, for example, that humans are not simply autonomous individuals but have always been part of a cultural tradition that provides orientation and direction in life and is not only cognitive, but also evaluative. ${ }^{21}$ In addition, we derive our expressions and our words from tradition. Language is not mine alone; it was not invented by me, and it shapes or frames me. As Taylor put it:

Experiences require some vocabulary, and these are inevitably in large part handed to us in the first place by our society, whatever transformations we may ring on them later. The ideas, the understanding with which we live our lives, shape directly what we could call religious experience; and these languages, these vocabularies, are never those simply of an individual (C. Taylor 2003: 40).

Here Taylor suggested that meaningful experiences in nature are felt collectively and often have a spiritual or religious depth dimension. Or as Joseph Champ noted, nature is a source of 'deeply meaningful experiences one might call religious or spiritual' (2009: 226). ${ }^{22}$

20. Some experiences can occur only if one has embraced a specific narrative. The same applies to the relationship between experiences and deep frames. These are dynamically involved with each other: they influence and correct each other. This is certainly true when we talk about experiences in nature. Nature provides us with experiences, and deep frames may function as a meaningful framework to interpret these experiences. On the other hand, a deep frame can shape certain experiences.

21. As human beings we need evaluative or moral horizons, or to quote Charles Taylor, 'frameworks of understanding', in order to relate to the world in which we are living (1989: 26). We need a shared moral space to distinguish between good and evil, on matters that are or are not worthwhile, interesting, or trivial.

22. On this topic Champ wrote, 'We are re-examining the way we have imagined meaning to happen in culture, opening the door for new possibilities, such as the realization that the influence of institutional religion is often important, but not always the only meaningful source in the public sphere' (2009: 237). Based on some other authors, Ross-Bryant spoke about three 'symbolic centers which have oriented people' in Western history: 'God, humanity and nature' (2013: 3). The process of orienting she denoted as religion: 'We can describe religion as the process of orienting self in community and world, establishing through negotiation how a community lives together in light of a larger purpose or meaning' (2013: 3-4). Bron Taylor remarked that the term 'spirituality' is nowadays replacing the word 'religion' more and more when referring to that which affects us at the deepest level. He pointed out that 'this usage has drawn the increasing attention of scholars, who seek to define the various meanings of spirituality and understand the perceptions and experiences that have led to the increasing popularity of this term' (B. Taylor 2001: 175).

(c) Equinox Publishing Ltd 2016.

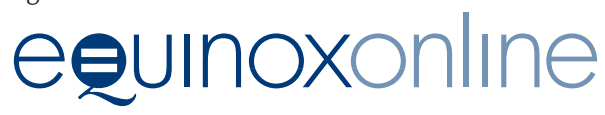




\section{Religious Depth Dimension ${ }^{23}$}

Several authors have noted that there is a religious revival going on in what Jeremy Stolow (2005) called 'secular modernity'. We live in a time that, to some, what was supposed to be secular has become sacred and what was traditionally associated with the sacred has been secularized (Hoover 1997). In the wake of modernity, religion did not disappear, but took a different shape and form: this 'new visibility of religion should not be taken to signal something entirely new, but rather to potentially reveal previously disguised aspects of religion' (Meyer 2012: 6). ${ }^{24}$

Authors including Stewart Hoover $(2002,2006)$ and Piet Winkelaar (2005) have concluded that religion must not only be interpreted in terms of institutions, doctrines, and structures. Hoover (1997) characterized current religiosity as 'doing' instead of 'belonging'. He observed that at the center of this 'doing' type of religiosity is the human as a seeking, questing, autonomous self. ${ }^{25}$ According to Hoover (2002), the present forms of religion focus more on the expressed and the experienced than on the ascribed. Along this line of thought, Stolow commented, 'It seems no longer possible to contain religion within the confines of "traditional" social logics of institutional loyalty, the performative demands of face-toface interaction, the controlled circulation of sacred texts, or the localized boundaries of "ritual time"' (2005: 122-23).

As he examined the roots of religion in the context of contemporary understandings, Bron Taylor (2010) came to the conclusion that religion has to do with that which connects and binds people to what they value most and consider or experience as sacred (see also B. Taylor 2001, 2004). An example of this can be found in this statement in Roots Magazine:

23. It is not the intention of this article to comment on what religion substantially is or is not. Rather, we seek ways to express what Liliane Voye called implicit religion, which 'refers to those aspects of ordinary life which seem to contain an inherently religious element within them-whether or not they are expressed in ways that are traditionally described as "religious"' (2004: 202). Ross-Bryant spoke of 'religion of everyday life' or 'lived religion' and observed that this 'will always be situated or contextualized, will always be dynamic, and will never be without ambiguities' (2013: 4).

3. In this context, Birgit Meyer's approach is interesting. She argued for a socalled 'post-secular' perspective 'that no longer takes secularization as the standard intrinsic to modernity, being alert instead to the specific ways in which the concept, role and place of religion-and its study-have been redefined with the rise of secularity' (2012: 6).

25. Hoover argued that traditional movements are becoming a smaller factor in contemporary religious practice and that in contemporary life, the ways of being religious have moved out of the protected sphere of religious institution and tradition, and into the open ground of the symbolic marketplace' (1997: 4).

(c) Equinox Publishing Ltd 2016.

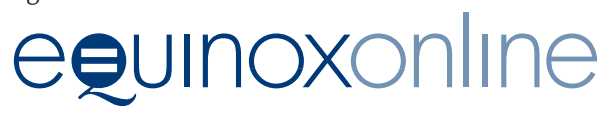


Michelangelo's portrayal of The Creation of Adam, of God and Adam reaching out to one another on the ceiling of the Sistine Chapel is famous the world over. Moments like that-of reaching out and finding one another-are the best. Very rarely will you have such an experience in nature. Practically every nature lover will have a vivid recollection of having become one with nature. Call it magical, call it divine (Roots Magazine 2013, Issue 10: 3).

Authors such as Hoover $(2002,2006)$ and Winkelaar (2005) argued that organized forms of religion no longer have a monopoly on religious experiences. Joke Van Saane (2002) held that religious experiences occur in situations in which humans are confronted with something or someone completely different that transcends everyday life and the perceptible reality. Alternately said, 'In the encounter with humans, nature becomes a source of imagination and can convey non-objective perceptible realities' (Waaijman 1994: 20). What is real and visible evokes thoughts and feelings 'which are not associated as much with that visible reality but rather with what is referred to' (Van Saane 2002: 49). The visible becomes a symbol, the visible refers to the invisible (Van Saane 2002). In this sense, religion becomes the practice of making the invisible visible through 'multiple media for materializing the sacred' (Orsi in Meyer 2012: 24), a bridge to make the absent visible, a possibility to connect 'there' to 'here'. ${ }^{26}$ Religion provides the content or 'material'for example, words, symbols, and rites-to interpret meaningful experiences in nature.

\section{Religious Subtexts}

The question arises as to what exactly these religious elements are and how they resonate in the discourse about nature, viz. communication of NGOs as well as in Dutch government policy on nature. The first salient fact is that both policy and the broader discourse appeal to an escape from daily life, as illustrated below:

Everyone needs to get away from the grind of everyday life, don't they? So why not take a trip and discover an island of tranquility, space and distant horizons (Natuurmonumenten 2012: n.p.).

Looking to enjoy the tranquility of the starry night sky? Then the island of Tiengemeten is the perfect place for you. Nature has been allowed to run its free course over the last few years. Tranquility and open spaces characterize the island, leaving the bustle of the Randstad far away.

26. Meyer (2012) approaches religion as a mediation practice through which a reality is created that is perceived and experienced as real. Her emphasis on mediation practice implies the need for what she calls material forms that can bring about this reality. For Meyer, the senses are the most religious instruments by far.

(c) Equinox Publishing Ltd 2016.

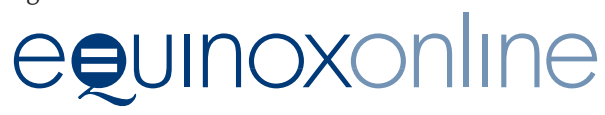


Tiengemeten is a popular location for day trippers looking for a relaxing day out. But you can only really unwind once on a lengthier stay... Leave behind the fast-track life of the city and come to rest. Spend the night on an uninhabited island, watch the sun rise over the Haringzliet, take a twilight walk while the birds float down to search for a nesting place. Take in the night sky as you've seldom seen it (VVV Zuid Holland Zuid 2012).

Often some sort of promise is made: recharge, find yourself, purify, come back reborn, a new world, and such:

The nature island in the Haringvliet is the place to recharge... The ferry voyage already gives you a sense of shedding the pressure of everyday life. And once you disembark on Tiengemeten, you're setting foot on a new world (Natuurmonumenten 2011: 20).

A network to end the fragmentation of nature. Its goal being to repair biodiversity and to create a stunning green environment for recreation, relaxation, a place to retreat from the humdrum of daily life in the urban jungle and find ourselves, to recharge and get on with it. Literally, to recreate (Nationaal GroenFonds 2010: 7).

In short, nature is referred to as being 'the better world', in which it becomes a sort of symbol for Paradise, with silence presented as an instrument for spiritual experience. ${ }^{27}$ Such sentiment is exemplified in the following passages:

Where in today's world is a place where the horizon stretches further than the eye, where there are no footpaths, and visitors can ponder amidst the birds? Where silence is audible, open space is tangible and you can come to rest? Where the waters are wild and untamed...feeding and drowning?... The world is miles away, worries melt and a smile breaks through (billboard, visitor center, Tiengemeten, Natuurmonumenten).

Nature is the perfect place for people to unwind... It offers the necessary space to find yourself in silence. Not only during the day, but at night when the flickering stars in the night sky add an extra dimension of rest and silence around you (Ministry of Agriculture, Nature and Fisheries [Ministerie van LNV] 2000: 9).

Waaijman (2000) pointed out that religious experiences do not have to be groundbreaking or transcendent experiences. They can also include experiences that affect human existence, serving as ethical encounters with nature that provide feelings of peace, silence, fear, truth, and/or beauty. Willis (2011) noted that wilderness has been rediscovered as the place of the sublime, which is often associated with an experience of

27. In 2009 the government asked to fill a vacancy with a communication professional who is able to bring the experience of silence to the attention of the public - one of the ideas is to promote Tiengemeten as an icon of silence.

(c) Equinox Publishing Ltd 2016.

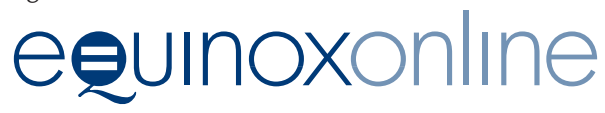


nature that is without comparison, grand, and overwhelming-an experience that goes beyond our sensual or intellectual capacities. This statement demonstrates how such perception can be reflected in public communication:

The Oostvaardersplassen. Open spaces stretching from horizon to horizon. A dynamic open space where all is connected. Marshes seamlessly meld into untouched, pristine reed banks. Nature is allowed to run its course, following the rhythm of the seasons and the circle of life. Over and over again. The inhabitants of the Oostvaardersplassen don't give it a second's thought. They hunt, fly, feed, rest and mate. It is eat or be eaten. It is life as it should be. In the here and now-no more, no less. Where earth and heaven intersect (billboard, visitor center, 'De Oostvaarders', Staatsbosbeheer).

In a sublime experience we transcend our sensory world and have an experience that exceeds us. We feel we are part of a reality that is larger than us, in which we experience how small we are, and at the same time we feel connection. The following show how this is reflected in discourse about nature in the Netherlands:

We believe that it is crucial that people foster a strong connection with nature... Make friends with animals, trees, plants, the sun and the stars. And discover who you truly are: one of Mother Nature's children (advertisement of Staatsbosbeheer 2014).

I'm in that landscape, I'm part of it. Unio mystica. Connection and total detachment at the same time. Nothing can happen to me (Sinke, dir., 2010).

Nash (2001 [1969]) intriguingly argued that sublimity implies a connection between God and the wilderness. ${ }^{28}$ Willis additionally noted

28. He refers to this as 'deism'. Nash noted that since the beginning of thought men have believed that natural objects and processes had 'spiritual significance', 'but "natural" evidence was usually secondary and supplemental to revelation. And wilderness, somewhat illogically, was excluded from the category of nature. The deists, however, based their entire faith in the existence of God on the application of reason to nature. Moreover, they accorded wilderness, as pure nature, special importance as the clearest medium through which God showed His power and excellency' (2001 [1969]: 46). Later he remarked that 'by the mid-eighteenth century wilderness was associated with the beauty and godliness that previously had defined it by their absence. People found it increasingly possible to praise, even to worship, what they had formerly detested' (2001 [1969]: 46). He also pointed out that in the course of time people began to perceive religious elements in nature itself. 'In the sweep of Western thought,' he argued, 'this was a relatively young idea, and one with revolutionary implications. If religion was identified with wilderness rather than opposed to it, as had traditionally been the case, the basis for appreciation, rather than hatred, was created' (Nash 2001 [1969]: 56). 'Romanticism, including deism and the aesthetics of the wild', he concluded later on, 'had cleared away enough of the old assumptions to

(c) Equinox Publishing Ltd 2016.

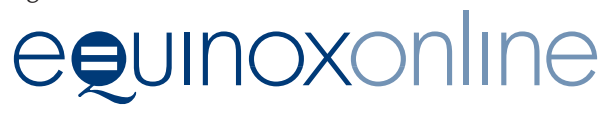


that through a sublime experience, 'certain landscapes came to be valued as holding the promise of revealing the face of God' (2011: 95). Conversely, we found no mention of (a personal) God in our study sample.

\section{Concluding Remarks}

In the Netherlands the concept of nature development has facilitated a new way of thinking about nature. Whereas the wilderness ideal previously led to the protection and conservation of endangered, pristine environments, today it serves as a justification for human interventions in the creation of 'new nature'. Nature development in itself, therefore, is paradoxical: it links with current ideas on technology, whilst striving to achieve a prehistorical type of nature independent from humankind. This means that a technical understanding of wilderness is central to the Dutch discourse of nature. In one sense, the technical attitude toward nature is still alive in the Netherlands through depoldering, which transforms farmland into wilderness. Nevertheless, there is an increased sense of loss of contact with nature, which has resulted in calls for 'more real nature', or wilderness. In the Netherlands, strictly speaking, there is no true wilderness remaining. Hence, the Dutch have attributed values such as 'real' or 'pure' to cultural landscapes in order to find any 'wilderness nature' in their country and have sought to create new wildernesses through nature development (ecosystem restoration).

Awareness of the interplay between surface frames and deep frames helps us to value more the discourse about nature for several reasons. First of all, we learn how communicating about nature is connected to worldviews. For, our views of nature convey more about how we perceive ourselves in relation to the natural reality than about the reality we call 'nature'. Further, we come to understand how contact with nature may lead to meaningful experiences. It is through communication (frames) that experiences become meaningful. Or more specifically, deep frames provide an interpretive context for our experiences with nature.

This study has hopefully shown that the discourse in the Netherlands on nature, as found in governmental and NGO produced communication about nature, contains religious subtexts that are not necessarily theological. Our examples suggest, rather, that nature is valorized and 'religionized' without any mention of a personal god or other supernatural agents. That might be part of the success of this discourse in a decreasingly Christian country.

permit a favorable attitude toward wilderness without entirely eliminating the instinctive fear and hostility a wilderness condition had produced' (2001 [1969]: 66).

(c) Equinox Publishing Ltd 2016.

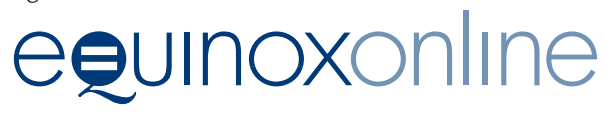




\section{References}

Buijs, Arjan E. 2009. Public Nature: Social Representations of Nature and Local Practices (PhD thesis: Wageningen University, The Netherlands).

Buijs, Arjan E., Birgit H.M. Elands, and Fransje Langers. 2009. 'No Wilderness for Immigrants: Cultural Differences in Images of Nature and Landscape Preferences', Landscape and Urban Planning 91.3: 113-23. Doi: http:/ /dx.doi.org/ 10.1016/j.landurbplan.2008.12.003.

Champ, Joseph G. 2009. 'Mediated Spectacular Nature: "God-centered" and "Naturecentered" Consumption of a Genre', Journal of Media and Religion 8.4: 226-41. Doi: http:/ /dx.doi.org/10.1080/15348420903305000.

Cronon, William. 1995. 'The Trouble with Wilderness, or Getting Back to the Wrong Nature', in W. Cronon (ed.), Uncommon Ground: Rethinking the Human Place in Nature (New York: W. W. Norton \& Co.): 69-90.

De Groot, Wouter T., and Riyan J.G. van den Born. 2003. 'Visions of Nature and Landscape Type Preferences: An Exploration in The Netherlands', Landscape and Urban Planning 63.3: 127-38. Doi: http://dx.doi.org/10.1016/S01692046(02)00184-6.

Drenthen, Martin. 2002. 'De Wilde Natuur en Verlangen naar Andersheid', in Voorsluis 2002: 65-86.

- 2003. Grenzen aan Wildheid: Wildernisverlangen en de betekenis van Nietzsches moraalkritiek voor de actuele milieu-ethiek (Budel: Damon).

_ 2011. 'Het leesbare landschap als woonplaats: Van lezend observeren naar plaatsverbondenheid', in van den Born et al. 2011: 121-41.

Ester, Hans. 2012. 'Romantiek versus Verlichting: een actuele uitdaging', Radix 38.1: 414.

Gorter, Hans Paul. 1986. Ruimte voor natuur, 80 jaar bezig voor de natuur van de toekomst ('s-Graveland: Vereniging tot Behoud van Natuurmonumenten in Nederland).

Hajer, Maarten A. 1995. The Politics of Environmental Discourse: Ecological Modernization and the Policy Process (Oxford: Oxford University Press).

2003. 'A Frame in the Fields: Policymaking and the Reinvention of Politics', in M.A. Hajer and H. Wagenaar (eds.), Deliberative Policy Analysis: Understanding Governance in the Network Society (Cambridge: Cambridge University Press): 88110. Doi: http:/ /dx.doi.org/10.1017/CBO9780511490934.005.

Hoover, Stewart M. 1997. 'Religion in a Media Age'. Public lecture. International Study Commission on Media, Religion \& Culture at the University of Edinburgh. 4 March. Online: http://www.ed.ac.uk/polopoly_fs/1.22781!/ fileManager $/$ religion $\% 20 \mathrm{in} \% 20 \mathrm{a} \% 20$ media $\% 20$ age.pdf.

. 2002. 'The Culturalist Turn in Scholarship on Media and Religion', Journal of Media and Religion 1.1: 25-36. Doi: http://dx.doi.org/10.1207/ S15328415JMR0101_4.

. 2006. Religion in Media Age (New York: Routledge).

Keulartz, Jozef. 2000. 'Naar een "beschaafde" strijd om de natuur', in Keulartz (ed.) 2000: 75-96.

- 2009a. 'Van ecologisch herstel tot ecologisch ontwerp; natuur in het tijdperk van globale veranderingen', Filosofie \& Praktijk 30.6: 44-59. 
2009b. 'European Nature Conservation and Restoration Policy: Problems and Perspectives', Restoration Ecology 17.4: 446-50. Doi:_http://dx.doi.org/10.1111/ j.1526-100X.2009.00566.x.

Keulartz, Jozef (ed.). 2000. Rustig, ruig en rationeel: Filosofische debatten over de verhouding cultuur-natuur (Baarn: Kasteel Groeneveld/ Staatsbosbeheer/ Wageningen University).

Keulartz, Jozef, Henny van der Windt, and Sjaak Swart. 2002. 'Natuurbeelden en natuurbeleid', Filosofie en Praktijk 23.1: 3-21.

- 2004. 'Concepts of Nature as Communicative Devices: The Case of Dutch Nature Policy', Environmental Values 13. 1: 81-99. Doi: http://dx.doi.org/ $10.3197 / 096327104772444785$.

Kockelkoren, Petran. 2000. 'Een leesbaar bokrijk', in Keulartz (ed.) 2000: 19-41.

Lakoff, George. 2006. Thinking Points; Communicating our American Values and Vision (New York: Farrar, Straus \& Giroux).

Lemaire, Ton. 2007 [1970]. Filosofie van het landschap (Amsterdam: Ambo).

McGrath, Alister E. 2001. A Scientific Theology. Vol. 1, Nature (Edinburgh: T. \& T. Clark).

Metz, Tracy. 1998. Nieuwe Natuur, reportages over veranderend landschap (Amsterdam: Ambo).

Meyer, Birgit. 2012. Mediation and the Genesis of Presence: Towards a Material Approach to Religion (Utrecht: Universiteit Utrecht).

Ministerie van Economische Zaken. 2014. Natuurlijk Verder; Rijksnatuurvisie 2014 (Den Haag: Ministerie van Economische Zaken).

Ministerie van LNV. 1989. Natuurontwikkeling: een verkennende studie (Den Haag: Ministerie van LNV).

. 1990. Natuurbeleidsplan: regeringsbeslissing (Den Haag: SDU).

-2000. Natuur voor mensen, mensen voor natuur: nota natuur, bos en landschap in de 21e eeuw (Den Haag: Ministerie van LNV).

Nash, Roderick F. 2001 [1969]. Wilderness and the American Mind (New Haven: Yale University Press).

Natuurmonumenten. 2011. Natuurbehoud Magazine, no. 2 ('s-Gravenland: Vereniging tot Behoud van Natuurmonumenten in Nederland).

- 2012. Kom naar Tiengemeten ('s-Gravenland: Vereniging tot Behoud van Natuurmonumenten in Nederland).

- 2014. Natuurbeleving nader bekeken ('s-Graveland: Vereniging tot Behoud van Natuurmonumenten in Nederland).

_. n.d. Weelde, Wildernis en Weemoed; ontdek natuureiland Tiengemeten ('sGravenland: Vereniging tot Behoud van Natuurmonumenten in Nederland).

Nationaal Groenfonds. 2010. Publiek geheim; succes van de EHS (Amsterdam: Nationaal Groenfonds).

Naugle, David K. 2002. Worldview: The History of a Concept (Grand Rapids: Eerdmans). Roothaan, Angela. 2005. Terugkeer van de natuur: De betekenis van natuurervaring voor een nieuwe ethiek (Kampen: Klement).

Ross-Bryant, Lynn. 2013. Pilgrimage to the National Parks: Religion and Nature in the United States (New York: Routledge).

Schouten, Matthijs G.C. 2002. 'Tussen Arcadië en Wildernis', in Voorsluis 2002: 16-37. . 2005. Spiegel van de natuur: Het natuurbeeld in cultuurhistorisch perspectief (Utrecht: KNVV/Staatbosbeheer). 
Sinke, Digna (dir.). 2010. Wistful Wilderness. Film trailer (Amsterdam: SNG Film).

Online: http:/ / www.sngfilm.nl/UK\%20Weemoed\%20\&\%20Wildernis.htm.

Stolow, Jeremy. 2005. 'Religion and/as Media', Theory, Culture E Society 22.4: 119-45.

Doi: http:/ /dx.doi.org/10.1177/0263276405054993.

Taylor, Bron. 2001. 'Earth and Nature-Based Spirituality (Part I): From Deep Ecology

to Radical Environmentalism', Religion 31.2: 175-93. Doi: http://dx.doi.org/ 10.1006/reli.2000.0256.

- 2004. 'A Green Future for Religion?', Futures 36.9: 991-1008. Doi: http:/ /dx.doi.org/10.1016/j.futures.2004.02.011.

. 2010. Dark Green Religion; Nature Spirituality and the Planetary Future (Berkeley:

University of California Press).

. 2012. 'Wilderness, Spirituality and Biodiversity in North America-Tracing an

Environmental History from Occidental Roots to Earth Day', in L. Felt (ed.), In

Wilderness Mythologies: Wilderness in the History of Religion (Berlin: W. de

Gruyter): 292-324. Doi: http://dx.doi.org/10.1515/9781614511724.293.

Taylor, Charles. 1989. Sources of the Self: The Making of the Modern Identity (Cambridge:

Cambridge University Press).

- 1991. The Ethics of Authenticity (London: Harvard University Press).

- 2003. Wat betekent religie vandaag? (Kapellen: Pelckmans/ Klement).

Van den Born, J.G. Riyan, and Mirjam de Groot. 2011. 'Favoriete plekken en binnendoorpaadjes. Op zoek naar de betekenis van landschap en verbondenheid met plaats', in van den Born et al. 2011: 10-26.

Van den Born, J.G. Riyan, M. Drenthen, P. Lemmens, and T. van Slobbe (eds.). 2011. Plaats: Beschouwingen over verbondenheid met natuur en landschap (Zeist: KNNV Uitgeverij).

Van der Windt, Henny, Sjaak Swart, and Jozef Keulartz. 2007. 'Nature and Landscape Planning: Exploring the Dynamics of Valuation, the Case of the Netherlands', Landscape and Urban Planning 79.3/4: 218-28. Doi: http:/ /dx.doi.org/10.1016/ j.landurbplan.2006.02.001.

Van Koppen, Chris S.A. 2002. Echte natuur: Een sociaal theoretisch onderzoek naar natuurwaardering en natuurbescherming in de moderne samenleving (Wageningen: Wageningen University).

Van Saane, Joke. 2002. 'De natuur in religieuze verbeelding', in Voorsluis 2002: 48-64.

Vera, Frans. 2000. 'Het primitieve natuurbeeld', in Keulartz 2000: 43-61.

Voorsluis, B. (ed.). 2002. De zwijgende natuur: Natuurervaring tussen betovering en onttovering (Zoetemeer: Meinema).

Voye, Liliane. 2004. 'A Survey of Advances of in the Sociology of Religion (19802000)', in P. Antes, A.W. Geertz, and R.R. Warne (eds.), New Approaches to the Study of Religion. Vol. 2. Textual, Comparative, Sociological and Cognitive Approaches (Berlin: W. de Gruyter): 195-228.

VVV Zuid Holland Zuid. 2012. Toeristische Gids Nationaal Landschap Hoeksche Waarde (Dordrecht: VVD Zuid Holland Zuid).

Waaijman, Cornelis J. 1994. Milieuspiritualiteit (Nijmegen: Titus Brandsma Instituut). - 2000. Spiritualiteit: Vormen, grondslagen, methoden (Kampen: Kok).

Willis, Alette. 2011. 'Re-Storying Wilderness and Adventure Therapies: Healing Places and Selves in an Era of Environmental Crises', Journals of Adventure Education \& Outdoor Learning 11.2: 91-108. Doi: http://dx.doi.org/10.1080/ $\underline{14729679.2011 .633375 .}$ 
Winkelaar, Piet. 2005. Anders dan we denken: Een geseculariseerde benadering van het religieuze (Amsterdam: SWP Uitgeverij).

Woud, Auke, van der. 2007. De blanke top der duinen; mooi Nederland en zijn historie (Den Haag: KVAN/Nationaal Archief).

Zwanniken, Tim. 2001. Ruimte als voorraad? Ruimte voor variëteit!; de consequenties van discoursen 'ruimte als voorraad' voor het rijks ruimtelijk beleid (Nijmegen: Radboud University).

Zwart, Hub. 2002. 'Een morele geschiedenis van het Nederlandse landschap', in Voorsluis 2002: 38-47.

. 2011. 'De tuin als landschapsarchief, laboratorium en dialoog', in van den Born et al. 2011: 72-85. 